\title{
Decision-making microRNAs (miR-124, $-133 a / b$, -34a and -134) in patients with occluded target vessel in acute coronary syndrome
}

\author{
Jacek Gacoń ${ }^{1}$, Anna Kabłak-Ziembicka², Ewa Stępieńn, Francisco J. Enguita ${ }^{4}$, Izabela Karch², \\ Bogusław Derlaga ${ }^{1}$, Krzysztof Żmudka², Tadeusz Przewłocki ${ }^{5}$ \\ 'Department of Invasive Cardiology, The Edward Szczeklik Hospital, Tarnow, Poland \\ 2Department of Interventional Cardiology, Institute of Cardiology, Jagiellonian University Medical College, John Paul II Hospital, Krakow, Poland \\ ${ }^{3}$ Department of Medical Physics, Faculty of Physics, Astronomy, and Applied Informatics, Jagiellonian University, Krakow, Poland \\ ${ }^{4}$ Instituto de Medicina Molecular, Faculdade de Medicina, Universidade de Lisboa, Lisboa, Portugal \\ ${ }^{5}$ Department of Cardiac and Vascular Diseases, Department of Interventional Cardiology, Institute of Cardiology, \\ Jagiellonian University Medical College, John Paul II Hospital, Krakow, Poland
}

\section{Abstract}

Background: Coronary artery occlusion does not always manifest with ST-elevation, and some patients can have patent coronary vessel.

Aim: We evaluated circulating microRNA (miRNA) profiles to discriminate subjects with infarct-related artery (IRA) occlusion.

Methods and results: Patients $(n=43)$ with uncomplicated acute coronary syndrome and positive troponins were classified with respect to patent vs. occluded IRA or ST-elevation vs. non-ST elevation MI (STEMI vs. NSTEMI). Expression levels of serum miRNAs (miR-1, -16, -34a, -122, -124, -208b, -133a/b, -375, and -499) were analysed. Out of 16 STEMI and 27 NSTEMI patients, IRA occlusion was noted in 12 and 15 patients, respectively. The remaining four STEMI and 12 NSTEMI patients had patent IRA. STEMI patients had higher troponin T levels and a 3.83-fold higher miR-134 expression ( $<<0.025)$. Patients with the occluded vs. patent IRA had higher levels of miR-133a (fold change: 7.00), miR-133b (4.57), miR-34a (5.50), miR-124 (2.55), and miR-134 (3.45) but no difference in troponin T levels. Receiver operator characteristic analysis identified decision-making miRNAs in occluded vessels: miR-124 (AUC: 0.787, $p<0.001$ ), miR-133b (AUC: 0.704, $p=0.006$ ), and miR-134 (AUC: $0.686, p=0.016$ ). With respect to STEMI, only miR-134 showed a discriminating value (AUC: $0.725, p=0.002$ ).

Conclusions: The degree of IRA occlusion determines circulating miRNA expression, and specific miRNAs may be useful in indicating patients requiring urgent coronary revascularisation.

Key words: acute coronary syndrome, mRNA, infarct-related artery, STEMI, NSTEMI, occluded

Kardiol Pol 2016; 74, 3: 280-288

\section{INTRODUCTION}

In acute coronary syndrome (ACS), early detection and implementation of a specific treatment and revascularisation determines preservation of the viable myocardium, according to the principle "time is muscle". Prompt regaining of the culprit vessel patency to restore myocardial perfusion significantly reduces the early and late mortality, and minimises the number of adverse events related to the post-ACS remodelling [1].
Currently, the ACS management focuses on: (1) electrocardiography (ECG), which distinguishes between ST-elevation (STEMI) and non-ST-elevation myocardial infarction (NSTEMI), (2) provided symptoms, and (3) positive tests for myocardial necrosis. Usually, STEMI is accompanied by epicardial coronary artery occlusion, whereas myocardial necrosis without ST-elevation is associated with the patent but stenosed coronary vessel [2]. 
However, numerous data indicate the possibility of infarct-related coronary artery (IRA) occlusion in the absence of ST-elevation, or specific changes connected with circumflex artery occlusion (such as ST abnormalities cause mirror changes in the V1-V3 leads or ST elevation in additional V7-V9 leads), which unfortunately leads to delays in diagnosis and revascularisation therapy [2].

Nevertheless, apart from ECG no specific markers have been proposed that could differentiate ACS with patent or occluded IRA. Recently, new potential diagnostic and prognostic biomarkers in ACS patients have emerged, e.g. heart-specific fatty acid-binding protein, copeptin, and matrix metalloproteinase-9 or carotid intima-media thickness [3, 4]. Particularly, when combined with cardiac-specific troponin they have the potential to improve the accuracy of diagnostics and prognosis in ACS. However, none of them is useful to distinguish between a patent and occluded infarct artery.

Circulating microRNAs (miRNAs) are recognised as small non-coding RNAs released from the ischaemic, damaged cells or as an instrument of communication in microvesicles. Those molecules consist of 19 to 25 non-coding nucleotides that regulate gene expression by hybridising to messenger RNAs (mRNAs) and causing mRNA degradation or translational inhibition [5]. Both atherosclerosis initiation and progression are regulated by these small non-coding sequences. Recent studies have shown that some miRNAs expression levels are modulated in ischaemic conditions [6]. Among them, serum levels of several miRNAs, are thought to be associated with organ ischaemia: abundant in human heart (miR-1, miR-133a/b, miR-208b and miR-499-5p), brain-secreted (miR-34a, miR-124 and miR-134), liver (miR-122), and pancreas (miR-375) [7]. Our selection criteria for miRNAs were mainly set based on previous reports analysing the potential usefulness of miRNAs as novel biomarkers of myocardial damage $[8,9]$. The serum miR-16 recommended for humans was used as a housekeeping miR in our study [10].

The purpose of our research was to evaluate the levels of selected serum miRNAs (miR-1, -34a, -122, -124, 133a/b, $-134,-208 b,-375$, and -499-5p), as well as markers depending on the ST changes on ECG and IRA patency in subjects with uncomplicated ACS admitted for coronary angiography and possible intervention procedure. Particularly, we intended to evaluate the impact of IRA occlusion on the expression of circulating miRNAs.

\section{METHODS}

\section{Study group}

The study comprised 43 consecutive patients ( $n=34$ male) in mean age $57.5 \pm 9.9$ years (range $40-79$ ) admitted to the Department of Invasive Cardiology, The Edward Szczeklik Hospital in Tarnow (Poland). Subjects had diagnosed uncomplicated myocardial infarction according to the European
Society of Cardiology (ESC)/American Heart Association (AHA) redefined guidelines. All patients underwent urgent coronary angiography and subsequent coronary intervention according to accepted ESC/AHA guidelines.

Inclusion criteria were as follows: age over 18 years old, and the presence of an infarct-related lesion in coronary artery identified during routine coronary angiography. Exclusion criteria included: any clinical signs of heart failure (in Killip classes II, III, and IV) observed before catheterisation, prior fibrinolysis, mechanical or electrical complications of ACS, left bundle branch block on ECG, anticoagulation, known malignant disease, active or chronic infection, or other inflammatory disease (e.g. systemic inflammation such as active chronic arthritis). All subjects signed an informed consent form in accordance with the requirements of the institutional local Ethics Committee. The study was performed consistent with the requirements of the Declaration of Helsinki.

According to ECG criteria, subjects were classified as STEMI ( $\mathrm{n}=16)$ and NSTEMI $(\mathrm{n}=27)$. Moreover, according to angiographic image, subjects were allocated to groups with patent vs. occluded IRA.

The distribution of classic risk factors (diabetes, hyperlipidaemia, arterial hypertension, smoking current or previous) was recorded (Table 1). Definitions of hypertension, diabetes, and hyperlipidaemia were adopted from the scientific statements of the ESC (http://www.escardio.org).

\section{Coronary angiography and revascularisation procedure}

Coronary angiography was performed from the femoral or radial approach by the Seldinger technique. The Thrombolysis in Myocardial Infarction (TIMI) flow grade scale was used to assess the target vessel patency. During coronary angiography, patients were classified into two groups with respect to flow grades. Patients who had TIMI flow grade 0 or 1 constituted the occluded IRA group, and patients revealing 2 or 3 TIMI flow comprised the IRA patent group, as previously described. All cineangiograms were reviewed by two independent observers.

Dual antiplatelet therapy (loading dose of acetylsalicylic acid [ASA] $300 \mathrm{mg}$ and clopidogrel $600 \mathrm{mg}$ ) was administered upon ACS recognition before coronary angiography. During the procedure unfractionated heparin was administrated according to patient weight and activated clotting time. Ilb/IIla glycoprotein inhibitors were used at the operator's discretion. Other medications, such as analgesics and beta-blockers were administrated according to clinical indications.

During revascularisation procedure, thrombectomy was attempted in the case of coronary occlusion or visible thrombus formation. IRA was routinely stented, predilation, and bare metal or drug eluting stent choice depended on the clinical circumstances and operator's decision. 
Table 1. Patients characteristics

\begin{tabular}{|c|c|c|c|c|c|c|}
\hline & $\begin{array}{c}\text { STEMI } \\
(\mathrm{n}=16)\end{array}$ & $\begin{array}{l}\text { NSTEMI } \\
(\mathrm{n}=27)\end{array}$ & $\mathbf{P}$ & $\begin{array}{l}\text { Occluded } \\
(n=27)\end{array}$ & $\begin{array}{l}\text { Patent } \\
(n=16)\end{array}$ & $\mathbf{P}$ \\
\hline \multicolumn{7}{|l|}{ Epidemiology } \\
\hline Age [years] & $57.5 \pm 9.64$ & $57.6 \pm 10.42$ & 0.97 & $58.9 \pm 11.22$ & $55.2 \pm 7.50$ & 0.25 \\
\hline Male & $14(87 \%)$ & $20(74 \%)$ & 0.29 & $23(85 \%)$ & $11(68 \%)$ & 0.20 \\
\hline Body mass index $\left[\mathrm{kg} / \mathrm{m}^{2}\right]$ & $30.1 \pm 4.83$ & $28.1 \pm 4.95$ & 0.19 & $29.1 \pm 4.83$ & $28.5 \pm 5.28$ & 0.69 \\
\hline Hypertension & $13(81 \%)$ & $20(74 \%)$ & 0.59 & $21(77 \%)$ & $12(75 \%)$ & 0.78 \\
\hline Diabetes & $9(53 \%)$ & $11(40 \%)$ & 0.32 & $13(46 \%)$ & $7(43 \%)$ & 0.95 \\
\hline Smoking & $10(62 \%)$ & $19(70 \%)$ & 0.59 & $19(70 \%)$ & $10(62 \%)$ & 0.59 \\
\hline PAOD & $1(5 \%)$ & $5(18 \%)$ & 0.26 & $4(14 \%)$ & $2(12 \%)$ & 0.83 \\
\hline Previous IS & $1(5 \%)$ & $0(0 \%)$ & 0.18 & $0(0 \%)$ & $1(6 \%)$ & 0.18 \\
\hline \multicolumn{7}{|l|}{ Biochemistry } \\
\hline hs-TnT $T_{\max }(\mathrm{Q} 1-\mathrm{Q} 3)[\mathrm{ng} / \mathrm{mL}]$ & $2.40(0.73-7.93)$ & $0.38(0.16-1.62)$ & 0.006 & $0.77(0.16-3.06)$ & $0.72(0.22-2.72)$ & 0.92 \\
\hline Creatinine [mmol/L] & $78 \pm 15.52$ & $77 \pm 15.0$ & 0.84 & $77 \pm 14.1$ & $79 \pm 16.9$ & 0.70 \\
\hline Glucose (Q1-Q3) [mmol/L] & $6.6(6.0-9.4)$ & $6.9(5.5-7.8)$ & 0.46 & $6.7(5.9-7.9)$ & $6.8(5.7-9.6)$ & 0.90 \\
\hline Total cholesterol [mmol/L] & $5.5 \pm 0.91$ & $5.7 \pm 1.64$ & 0.65 & $5.7 \pm 1.22$ & $5.4 \pm 1.7$ & 0.37 \\
\hline LDL-C (Q1-Q3) [mmol/L] & $3.3(2.88-4.16)$ & $4.0(3.2-4.4)$ & 0.31 & $3.8(3.1-4.3)$ & $3.6(3.0-4.3)$ & 0.92 \\
\hline HDL-C (Q1-Q3) [mmol/L] & $1.2(1.0-1.5)$ & $1.1(0.9-1.4)$ & 0.59 & $1.2(0.9-1.4)$ & $1.1(0.9-1.4)$ & 0.96 \\
\hline Triglycerides (Q1-Q3) [mmol/L] & $1.0(0.8-2.1)$ & $1.5(1.0-2.9)$ & 0.34 & $1.2(0.9-2.0)$ & $1.5(0.8-2.5)$ & 0.65 \\
\hline \multicolumn{7}{|l|}{ Various } \\
\hline ABI (Q1-Q3) & $1.13(0.99-1.19)$ & $1.04(0.88-1.21)$ & 0.31 & $1.08(0.96-1.19)$ & $1.05(0.90-1.21)$ & 0.73 \\
\hline LVEF (Q1-Q3) [\%] & $55(52-63)$ & $57(51-63)$ & 0.59 & $55(50-60)$ & $56(52-60)$ & 0.54 \\
\hline Pain onset (Q1-Q3) [h] & $3(1.7-6)$ & $9(5-20)$ & $<0.001$ & $6(3-13)$ & $7(3.5-19)$ & 0.53 \\
\hline
\end{tabular}

Values are given as mean and standard deviation (SD), median with interquartile interval (Q1-Q3), or the number and percentage (\%). Bold value denotes statistically significant differences between both groups; $\mathrm{ABI}$ - ankle-brachial index; HDL-C — high-density lipoprotein cholesterol; $\mathrm{hs}^{-\mathrm{TnT}_{\max }}$ - highly-sensitive troponin T; LDL-C — low-density lipoprotein cholesterol; LVEF — left ventricular ejection fraction; PAOD — peripheral artery occlusive disease; IS - ischaemic stroke

\section{Laboratory tests}

The standard blood tests included serum glucose, hs-C-reactive protein, fibrinogen levels and lipid profile assessment. Serial hs-troponin T levels (Roche Diagnostics, Basel, Switzerland) were obtained, and the maximum hs-troponin $\mathrm{T}$ values were analysed (hs-TnT $\mathrm{Tax}_{\max }$ ).

\section{MicroRNA extraction}

Blood samples for candidate miRNAs were collected on patient admission to the cardiac unit, after heparin treatment. Samples were allowed to coagulate for $30 \mathrm{~min}$, centrifuged, and sera were frozen at $-80^{\circ} \mathrm{C}$ until miRNA and selected biomarkers analysis. Extraction of miRNA was performed by means of the miRNeasy Serum/Plasma Kit (kat. No 217184, Qiagen) with the initial lysis by Trizol LS Reagent (kat. No 10296-028, Invitrogen). The RNA yield and concentrations were determined by capillary electrophoresis on an Agilent Bioanalyser 2100 with the Eukaryote Total RNA Pico Chip (Agilent Technologies, Inc., Santa Clara CA). An average $60 \pm 31.9 \mathrm{pg} / \mathrm{mL}$ of total RNA from $300 \mathrm{~mL}$ of serum was recovered.

\section{Profiling of candidate miRNAs}

At the time of the study, Exiqon LNA primers were used to quantify 10 mature miRNAs using the ViiA 7 real-time polymerase chain reaction (PCR) system equipped with a 384-well reaction plate (Life Technologies). RNA was converted to cDNA using the Universal cDNA Synthesis Kit (kat. No. EQ-203300, Exiqon). Before synthesis, RNAs were spiked with a synthetic miRNA that served as a control for the cDNA synthesis reaction. Real-time PCR was performed in triplicate with SYBR Green master mix Universal RT (kat. No. EQ-203400, Exiqon) using standard conditions. The organ-specific candidate miRNAs were selected: cardiac and skeletal muscle (miR-1, -133a, -133b, -208b, -499), brain-related (miR-34a, -124, -134), liver (miR-122), pancreas (miR-375), and a reference miR for serum (miR-16).

Data were processed by the delta-delta-Ct method $\left(2^{-\Delta \Delta C t}\right)$, using a global normalisation approach as implemented in the open source DataAssist software (Life Sciences). The fold changes (RQ) in patented vs. occluded vessels and STEMI vs. NSTEMI patients were calculated. Hierarchical clustering of median-normalised miRNA values was performed using Cluster 3.0 software [11]. 


\section{Statistical analysis}

It was established whether the continuous data followed the normal distribution by the Kolmogorov-Smirnov test. Continuous variables are presented as the mean value \pm standard deviation (SD). Categorical variables were expressed as absolute values, percentages, or both and compared by means of $\chi^{2}$ or Fisher test. Differences between mean values were verified using the Student's t test when the distribution of variables was normal, in other cases applying the test Mann-Whitney $U$. The fold-change analysis of miRNA levels was performed by the non-parametric Kolmogorov-Smirnov test for datasets comparison. Differences in qualitative variables (categorical) were verified by $\chi^{2}$ test. A p value less than 0.05 was considered statistically significant. Clinical accuracy of significant miRNAs was assessed using receiver operator characteristic (ROC), and the area under the curve (AUC) was calculated for each of the miRNAs of interest separately using DeLong's method. For those cutoffs, positive and negative predictive values, as well as sensitivity and specificity, were calculated. Analyses were performed with Statistica Version 10 (StatSoft, Inc.) and Excel (Microsoft) software.

\section{RESULTS}

The entire group of ACS patients was thoroughly allocated into four partially overlapping subgroups. According to ECG criteria, there were 16 STEMI and 27 NSTEMI patients identified. IRA occlusion was noted in 12 (75\%) out of 16 subjects with STEMI, and in 15 (55.6\%) out of 27 patients with NSTEMI $(p=0.002)$. The remaining four $(25 \%)$ patients with STEMI and 12 (44.4\%) with NSTEMI had patent IRA.

Patients with STEMI had significantly higher maximum hs-TnT levels, as compared to NSTEMI subjects (Table 1). Despite the high proportion of IRA occlusion in patients with NSTEMI, NSTEMI patients had significantly longer time from symptoms onset to revascularisation procedures compared to STEMI (Table 1).

In our study group, we did not find any other differences between STEMI and NSTEMI patients, as well as patent vs. OCcluded IRA (Table 1).

\section{Circulating miRNAs in ACS patients}

Analysis of average cycle threshold (Ct) for each of the miRNAs revealed that miR-208 and miR-499 had relatively low abundance in serum (40.0). For miR-1, -122, -124, -133a, $-133 b,-134,-16,-34 a$, and -375 average Ct values were $39.41,37.27,34.96,37.53,35.75,36.09,37.25,36.04$ and 33.85 , respectively. The maximum allowable Ct was 40.0.

There was no statistical significance in the miRNA fold levels in STEMI vs. NSTEMI subjects, except for miR-134, the level of which was 3.83-fold higher in the STEMI group $(p<0.025)$ (Fig. 1). Additionally, the comparison of $2^{-\Delta \Delta C t}$ for every selected miRNAs was performed, which confirmed statistical significance for miR-134 (Fig. 1).

Discrimination of patients according to the target vessel occlusion criteria revealed that patients with occluded IRA had significantly higher levels of circulating cardiac and/or muscle-specific miR-133a and miR-133b, with the change fold: 7.00 ( $p<0.05$ ) and 4.57 ( $p<0.05$ ), respectively (Fig. 1). Similarly, brain-specific miR-34a, -124, and -134 showed significant increase in the occluded group: $5.50(p<0.05)$, 2.55 ( $p<0.025)$, and 3.45 ( $p<0.05$ ), respectively (Fig. 1). The $2^{-\Delta \Delta C t}$ comparison confirmed that significance (Fig. 1).

\section{Clustering of circulating miRNAs to enhance diagnostic discrimination of ACS patients}

For enhancement of the diagnostic discrimination of ACS patients the common pattern from unsupervised hierarchical clustering was applied. The analysis of the 10 miRNA levels

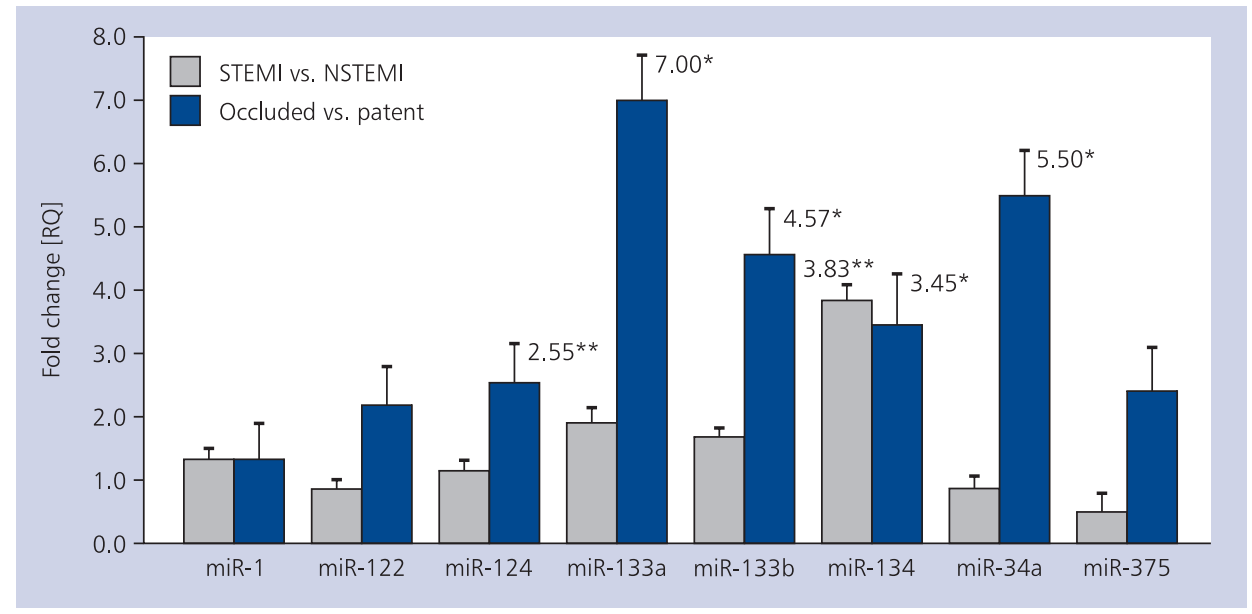

Figure 1. Comparison of analysed microRNA expressions in patients with acute coronary syndrome (ACS) by fold change (RQ) analysis significance in microRNA expression $\left(2^{-\Delta \Delta C t}\right)$ in ST elevation myocardial infarction (STEMI) and non-ST elevation myocardial infarction (NSTEMI) patients, and patients with patent vs. occluded target vessel; ${ }^{*} p<0.05 ;{ }^{* *} p<0.025$ 
( $\Delta$ Ct plus) with the Euclidian distance measurement was performed. As shown in Figure 2, the algorithm clustered the patients with occluded and patent vessel with several outliers. The discrimination pattern did not exhibit clear motives, but it plainly demonstrated that significant miRNAs (miR-34a, $-124,-133 a,-133 b,-134)$ are upregulated in most subjects with occluded IRA. In case of STEMI vs. NSTEMI, the discrimination pattern expressed less organised clustering (Fig. 2).

\section{ROC analysis of significant miRNAs in ACS patients}

To evaluate the predictive value of upregulated miRNAs, the ROC curves were calculated for each of the best miRNAs. In the case of the STEMI/NSTEMI group, the most predictive miRNA (miR-134) achieved AUC values of up to 0.725 (Fig. 3A, Table 2). Using miR-134 discrimination, 11 subjects were correctly classified as STEMI and 20 as NSTEMI with a sensitivity of $87.5 \%$ and specificity of 59.3\% (AUC: $0.725, p=0.002$ ).

The following predictors of IRA occlusion were identified by ROC analysis (Table 2): miR-124 (AUC 0.787), miR-133b

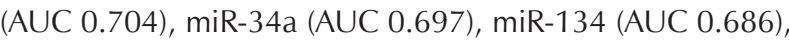
and miR-133a (AUC 0.640).

\section{DISCUSSION}

In the present study, we compared serum profile of candidate miRNAs in 43 patients with troponin-positive ACS classified as STEMI $(n=16)$ and NSTEMI $(n=27)$. After the angiography, patients were re-classified in terms of TIMI flow grade in IRA. Importantly, although in the STEMI group there were significantly more patients with occluded IRA than in the NSTEMI group, 56\% of NSTEMI subjects presented with occluded target vessel. Thus, these two classifications did not match each other (Fig. 4).

The potential clinical significance of our finding is that increased levels of some miRNAs might be associated with IRA occlusion, thus miRNAs expression might indicate subjects in whom coronary angiography should be performed without further delay due to artery occlusion. This finding is particularly important in patients with NSTEMI or non-diagnostic ECG, in whom the decision to perform coronary intervention can be urgently implemented to improve the survival and clinical outcome. In some patients the target vessel may have opened spontaneously during a period preceding interventional procedures. In such patients increase in circulating miRNAs may be the additional criterion to predict post-ischaemic complications [12].

Circulating skeletal muscle and cardiac-derived miRNAs have been extensively related with cardiac conditions $[6,9$, 13-15]. However, the utility of emergent miR-1, -208, and -499 in ACS diagnostics or differentiation has been tempered [5, 8, 14]. In the work by Wang et al. [5], as well as Widera et al. [8], higher expression of miR-208a was found in patients with cardiac ischaemia, as compared to healthy subjects or subjects with unstable angina, respectively. Taking into consideration such uncertainties, we have focused on the identification and potential use of non-cardiac miRNAs in the serum. Interestingly, a dramatic increase of circulating liver-specific miR-122 levels has been also related with cardiogenic shock in model systems [16]. Other miRNAs from apparently unrelated origin have been implicated in cardiac-related events. For instance, the brain-enriched miR-34a was described as an apoptosis-promoting factor after myocardial infarction [17], and the pancreatic miR-375 was characterised as a miRNA involved in embryonal heart development in mice [18]. Moreover, this evidence suggests a possible cross-talk communication between organs and distant control mediated by miRNAs. In order to cover some of these relationships and to analyse them in the context of ACS, small panel of miRNAs was selected for analysis in the patient cohort, containing miRNAs from several origins: skeletal muscle miRNAs (miR-1, miR-133a and miR-133b), cardiac-specific miRNAs (miR-208b and miR-499), pancreatic (miR-375), liver-specific (miR-122), and brain-enriched miRNAs (miR-34a, miR-124, and miR-134). In addition, miR-16 was also quantified as a possible housekeeping circulating miRNA taking into consideration the fact that miR-16 has been shown in some cases not to be a perfect normaliser, not because of the Ct levels but because of its variability among samples.

We observed that circulating heart-enriched miRNAs (miR-133a, -133b) were significantly elevated in patients with an occluded culprit coronary artery, in comparison to those with patent IRA. This finding might be explained by the fact that a degree of miR-133 family upregulation correlates with the extent of myocardial damage [7, 19], which should be higher in occlusions. Nevertheless, troponin levels did not differ significantly between patent vs. occluded IRA, thus this issue requires further elucidation. Moreover, the discriminating power of the miR-133 family was moderate; the AUC values ranged between 0.640 and 0.704 for miR-133a and miR-133b, respectively.

Surprisingly, the brain-related miRNAs were the most specific for IRA occlusion, particularly miR-124, for which the ROC analysis showed an AUC value of 0.787 , which makes it a reasonable marker. The other discriminating brain-related miRNAs, of lesser value, were miR-34 (AUC 0.697) and miR134 (AUC 0.686).

This finding might indicate that expression of the brain miRNAs might be more specific for organ ischaemia and perhaps related to the underlying mechanisms of ischaemia, like platelets activation, inflammation, or endothelial dysfunction. MiR-124 is associated with monocyte/macrophage cells, and it is reported to be most strongly associated with pro-inflammatory pathways [20]. Also, miR-34a is an important player in endothelial senescence, cardiac contractile function, and apoptosis. In vitro, miR-34a suppresses the expression of PNUTS (protein phosphatase 1 nuclear-targeting 


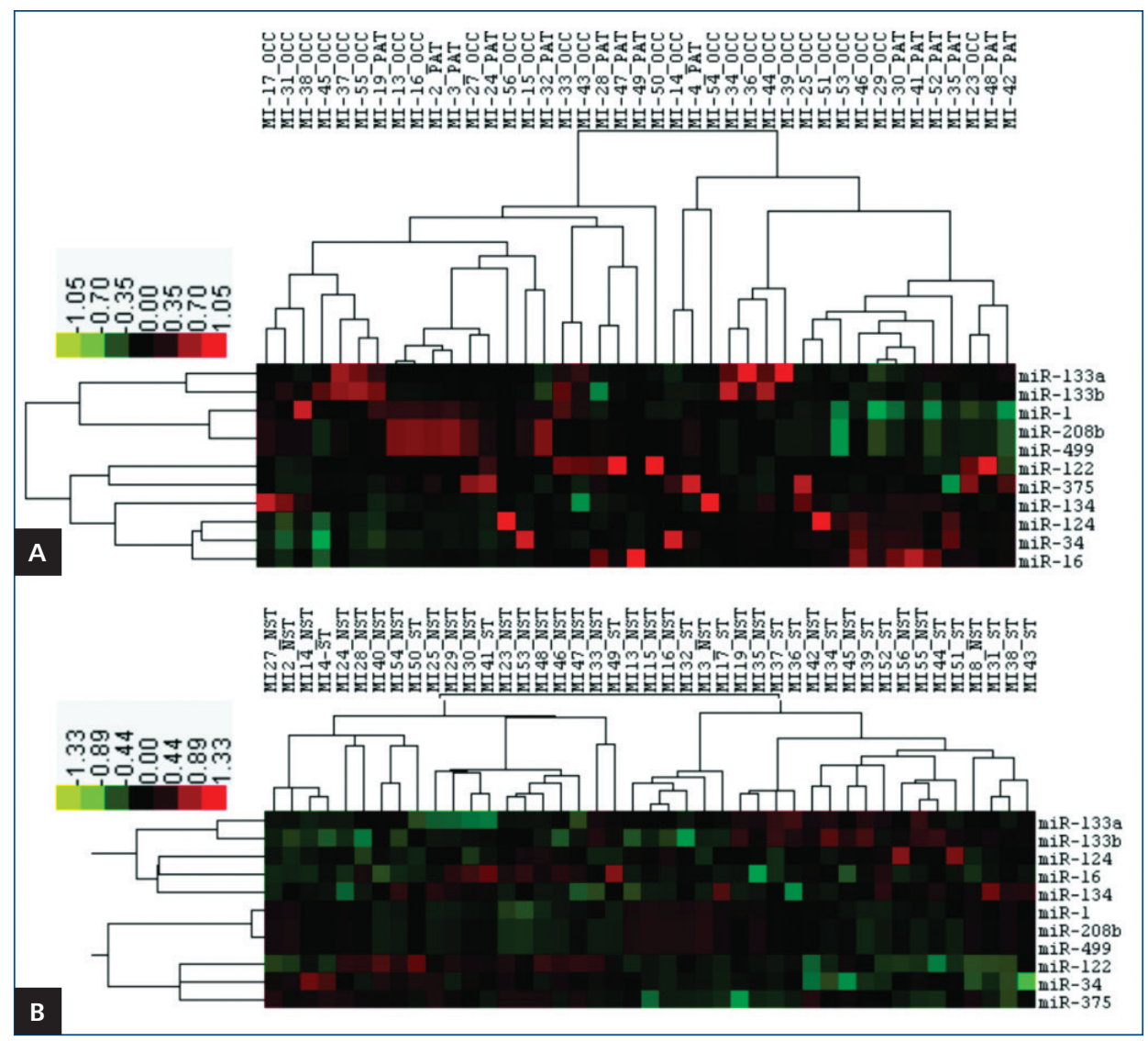

Figure 2. Hierarchical clustering of median-normalised microRNA expression data in serum samples from selected patients. Patients are depicted by a code followed by an abbreviation of the working group to which they belong: OCC — occluded; PAT — patent; ST — ST elevation myocardial infarction (STEMI); NST — non ST elevation myocardial infarction (NSTEMI);

A. Patent vs. occluded patients; B. STEMI vs. non-STEMI patients

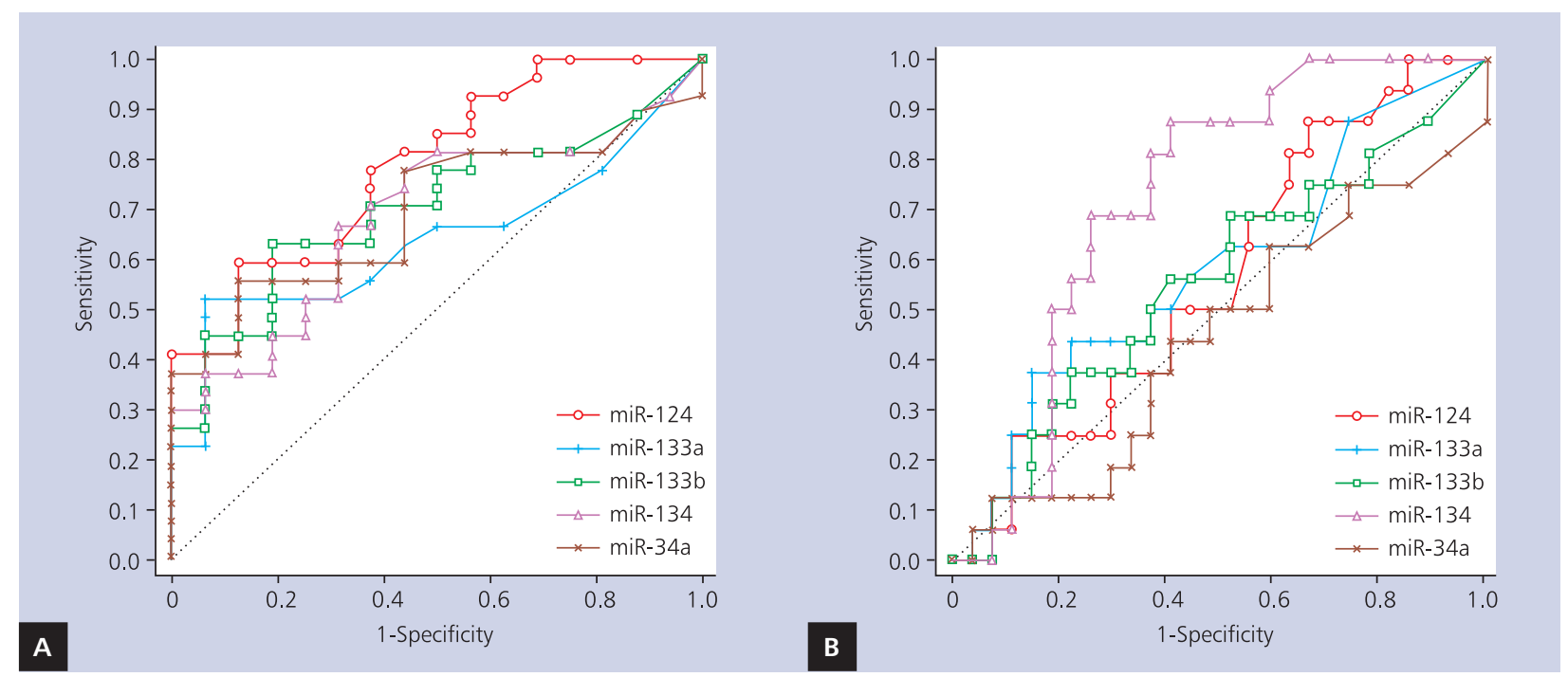

Figure 3. Receiver operator characteristic curves analysis in acute coronary syndrome (ACS) patients for selected microRNAs; A. MicroRNAs discriminating value for patent vs. occluded infarct related artery in ACS; B. MicroRNAs discriminating value for ST elevation myocardial infarction (STEMI) vs. non-ST elevation myocardial infarction (NSTEMI) patients 
Table 2. Results of receiver operator characteristic analysis for differentiating complications in acute coronary syndrome patients

\begin{tabular}{|c|c|c|c|c|c|c|c|c|}
\hline MicroRNA & AUC & $95 \% \mathrm{Cl}$ & $\begin{array}{c}\text { Standard } \\
\text { error }\end{array}$ & $\begin{array}{c}\text { Sensitivity } \\
{[\%]}\end{array}$ & $\begin{array}{c}\text { Specificity } \\
{[\%]}\end{array}$ & $\begin{array}{l}\text { PPV } \\
{[\%]}\end{array}$ & $\begin{array}{l}\text { NPV } \\
{[\%]}\end{array}$ & $\mathbf{P}$ \\
\hline \multicolumn{9}{|c|}{ STEMI vs. NSTEMI patients } \\
\hline miR-34a & 0.447 & $0.270-0.623$ & 0.090 & 12.5 & 93 & 50 & 64 & 0.555 \\
\hline miR-124 & 0.438 & $0.264-0.611$ & 0.089 & 87.5 & 33.3 & 43.8 & 81.8 & 0.464 \\
\hline miR-133a & 0.582 & $0.418-0.747$ & 0.084 & 37.5 & 85.2 & 60 & 69.7 & 0.327 \\
\hline miR-133b & 0.553 & $0.378-0.729$ & 0.089 & 68.8 & 48.1 & 44 & 72.2 & 0.552 \\
\hline miR-134 & 0.725 & $0.571-0.878$ & 0.076 & 87.5 & 59.3 & 56 & 88.9 & 0.002 \\
\hline \multicolumn{9}{|c|}{ Patent vs. occluded IRA } \\
\hline miR-34a & 0.697 & $0.539-0.854$ & 0.080 & 55.6 & 87.5 & 88.2 & 53.8 & 0.009 \\
\hline miR-124 & 0.787 & $0.649-0.924$ & 0.070 & 59.3 & 87.5 & 88.9 & 56 & $<0.001$ \\
\hline miR-133a & 0.640 & $0.474-0.805$ & 0.084 & 51.9 & 93.8 & 93.3 & 53.6 & 0.049 \\
\hline miR-133b & 0.704 & $0.547-0.860$ & 0.080 & 63.0 & 81.3 & 85 & 56.5 & 0.006 \\
\hline miR-134 & 0.686 & $0.524-0.848$ & 0.083 & 66.7 & 68.8 & 78.3 & 55 & 0.016 \\
\hline
\end{tabular}

AUC — the area under the receiver-operator characteristic curve; $\mathrm{Cl}$ — confidence interval; IRA — infarct related artery; NPV — negative predictive value; PPV — positive predictive value; STEMI — ST segment elevation myocardial infarction; NSTEMI — non-ST segment elevation myocardial infarction

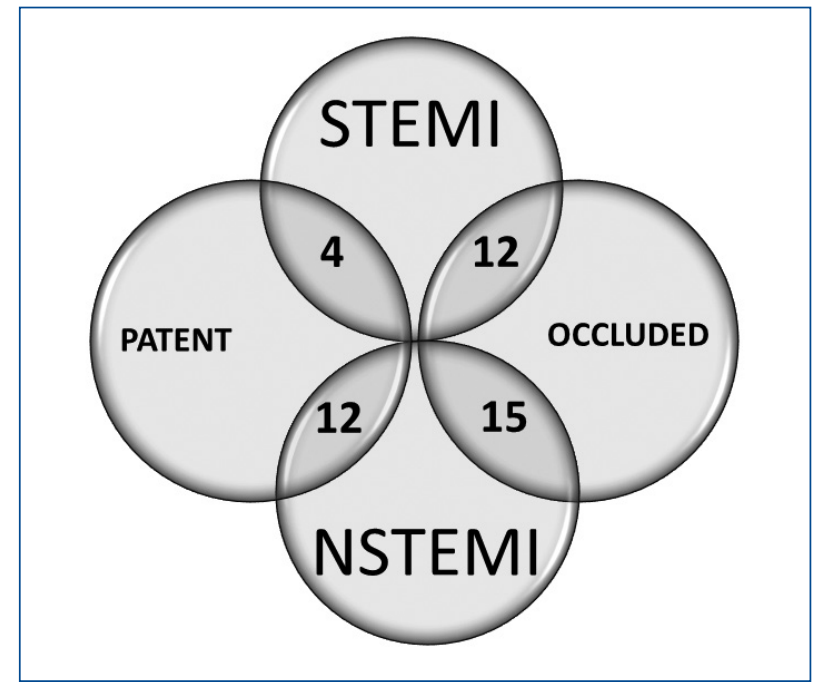

Figure 4. Distribution of acute coronary syndrome (ACS) patients, according to their clinical and vascular complications; STEMI — ST elevation myocardial infarction; NSTEMI — non-ST elevation myocardial infarction

subunit), which inhibits telomere shortening, DNA damage response, and apoptosis, possibly also in cardiomyocytes [21]. Interestingly, a recent report has indicated that the expression of miR-134 was 3.5-fold higher in the peripheral blood mononuclear cells of unstable angina pectoris patients, compared to those with stable angina pectoris [22].

On the other hand, it may be assumed that upregulation of brain miRNAs starts signalling pathways for targeted tissues/cells in response to occluded IRA. For example, there is increasing evidence for overlapping miRNA functions in different disease entities, such as cancer, and neurodegenerative or cardiovascular disease [23]. Although there is a huge concentration of miR-124 in the brain tissue, particularly in the cortical neurons, miR-124 leads to the repression of numerous non-neuronal miRNAs (i.e. connected with such biochemical pathway as lipolysis), expressed at low levels in the brain and at high levels in other tissues. Thus, miR124 may play a key role in signalling, resulting in the direct binding to hundreds of transcripts [20]. Existing data from studies of miR-124 and miR-134 are scarce and certainly require re-evaluation, especially in patients with ACS. In an observational study of patients with myocardial infarction, miR-134 was significantly higher in acute myocardial infarction patients than in healthy controls, and increased miR-134 levels were strongly associated with increased risk of mortality or heart failure within six months (odds ratio 2.28, 95\% confidence interval 1.03-11.32 p < 0.001) [24].

In our study, we found significant increase of these two NeuroMirs, and additionally miR-34a, thus we may take into consideration that there is a possible link between brain and a heart during ischaemia, on the intercellular communication level, via extracellular vesicles.

It is interesting that this miRNA expression profile was not replicated if patients were arranged according to STEMI/ /NSTEMI criteria, indicating again the possible heterogeneity of ACS. With respect to the STEMI vs. NSTEMI group, only miR-134 showed a moderate discriminating value (AUC 0.725, sensitivity $87.5 \%$, specificity $59.3 \%, p=0.002$ ). However, neither of them was superior to hs-cTnT for the diagnosis [25].

Former studies indicated higher levels of miR-1 and miR-499 in subjects with ACS as compared to healthy cohort; however, in the present study their expression did not differen- 
tiate subjects with NSTEMI/STEMI or patent/occluded IRA [25]. Those miRNAs are thought to be highly specific for cardiomyocytes, but, as some studies indicate, their levels are greatest in later phases of ACS and the post-myocardial infarction period, rather than on symptom presentation. It has been reported that miR-1 and miR-499 levels increased from 100-fold to 300-fold within $12 \mathrm{~h}$ after onset of symptoms, making them probably late markers of necrosis, and correlated with troponin T level or creatinine kinase-MB [25]. However, neither miR-499 nor miR-208 was associated with long-term mortality [26]. In these specific miRNAs, other factors may have an impact on the miRNAs expression, like time from symptom to coronary angiography and blood sample collection, or patient-specific factors (age, body mass index, medications) [26]. In our study we did not find any correlation between epidemiologic factors, treatment, and miRNA levels, although the influence of specific drugs or obesity cannot be excluded.

\section{Limitation of the study}

Some limitations of our study merit consideration. Firstly, we sampled patients' blood after heparin treatment. It is always an issue whether patient heparinisation affects laboratory analysis. In coagulation tests, heparin influence is substantial; in the case of molecular analysis, the miRNA extraction methods normally diminish the potential inhibition caused by heparin in a treatment dose. Secondly, we limited our investigation to a clinical cohort of ACS subjects without healthy controls. Thirdly, there was no kinetic analysis of circulating miRNA signatures. The time course of circulating miRNA levels may bring us some additional information about the dynamic changes of the human miRNome during ACS and may refine clinical diagnosis in such patients [6]. Nevertheless, we focused our interest on patients with ACS to find any significant differences in miRNA signatures corresponding to IRA occlusion not assuming to have deeper insight into post-ischaemic events and repair mechanism.

\section{CONCLUSIONS}

In the present study, except for miR-134, there were no obvious differences in the miRNA profile in patients with STEMI and with NSTEMI. The most important entity for miRNA expression is target vessel occlusion. Patent arteries produce less circulating NeuroMirs and miR-34a, both cardiac and brain specific. It may suggest a different pathomechanism of cell damage during myocardial infarction-related ischaemia, even in distant organs. Our observation may help to elucidate the mechanisms of ACS.

This study was supported by the KNOW project 2012-2017 (Faculty of Medicine Jagiellonian University Medical College as National Leading Centre) for E. Stępieńs visiting grant in Universidade de Lisboa.

Conflict of interest: none declared

\section{References}

1. Antman EM. Time is muscle: translation into practice. J Am Coll Cardiol, 2008; 52: 1216-1221. doi: 10.1016/j.jacc.2008.07.011.

2. Krishnaswamy A, Lincoff AM, Menon V. Magnitude and consequences of missing the acute infarct-related circumflex artery. Am Heart J, 2009; 158: 706-712. doi:10.1016/j.ahj.2009.08.024.

3. Kehl DW, Iqbal N, Fard A et al. Biomarkers in acute myocardial injury. Transl Res, 2012; 159: 252-264. doi: 10.1016/j.trsl.2011.11.002.

4. Kabłak-Ziembicka A, Przewłocki T, Pieniazek P et al. The role of carotid intima-media thickness assessment in cardiovascular risk evaluation in patients with polyvascular atherosclerosis. Atherosclerosis, 2010; 209: 125-130. doi: 10.1016/j.atherosclerosis.2009.08.019.

5. Wang GK, Zhu JQ, Zhang JT et al. Circulating microRNA: a novel potential biomarker for early diagnosis of acute myocardial infarction in humans. Eur Heart J, 2010; 31: 659-666. doi: 10.1093/eurheartj/ehq013.

6. D'Alessandra Y, Devanna P, Limana F et al. Circulating microRNAs are new and sensitive biomarkers of myocardial infarction. Eur Heart J, 2010; 31: 2765-2773. doi: 10.1093/eurheartj/ehq167.

7. Orenes-Piñero E, Montoro-García S, Patel JV et al. Role of microRNAs in cardiac remodelling: new insights and future perspectives. Int J Cardiol, 2013; 167: 1651-1659. doi: 10.1016/j.ijcard.2012.09.120.

8. Widera C, Gupta SK, Lorenzen JM et al. Diagnostic and prognostic impact of six circulating microRNAs in acute coronary syndrome. J Mol Cell Cardiol, 2011; 51: 872-875. doi: 10.1016/j.yjmcc.2011.07.011.

9. Oerlemans MI, Mosterd A, Dekker MS et al. Early assessment of acute coronary syndromes in the emergency department: the potential diagnostic value of circulating microRNAs. EMBO Mol Med, 2012; 4: 1176-1185. doi: 10.1002/emmm.201201749.

10. Song J, Bai Z, Han W et al. Identification of suitable reference genes for qPCR analysis of serum microRNA in gastric cancer patients. Dig Dis Sci, 2012; 57: 897-904. doi: 10.1007/s10620-011-1981-7.

11. de Hoon MJL, Imoto S, Nolan J, Miyano S. Open Source Clustering Software. Bioinformatics 2004; 20: 1453-1454. doi: 10.1093/bioinformatics/bth078

12. Devaux Y, Vausort M, McCann GP et al. A panel of 4 microRNAs facilitates the prediction of left ventricular contractility after acute myocardial infarction. PLoS One, 2013; 8: e70644. doi: 10.1371/journal.pone.0070644.

13. Eitel I, Adams V, Dieterich P et al. Relation of circulating MicroRNA-133a concentrations with myocardial damage and clinical prognosis in ST-elevation myocardial infarction. Am Heart J, 2012; 164: 706-714. doi: 10.1016/j.ahj.2012.08.004.

14. Corsten MF, Dennert R, Jochems S et al. Circulating MicroRNA-208b and MicroRNA-499 reflect myocardial damage in cardiovascular disease. Circ Cardiovasc Genet, 2010; 3: 499-506. doi: 10.1161/CIRCGENETICS.110.957415

15. D'Alessandra Y, Carena MC, Spazzafumo L et al. Diagnostic potential of plasmatic MicroRNA signatures in stable and unstable angina. PLoS One, 2013; 8: e80345. doi: 10.1371/journal.pone.0080345.

16. Andersson P, Gidlöf O, Braun OO et al. Plasma levels of liver-specific miR-122 is massively increased in a porcine cardiogenic shock model and attenuated by hypothermia. Shock, 2012; 37: 234-238. doi: 10.1097/SHK.0b013e31823f1811.

17. Fan F, Sun A, Zhao H et al. MicroRNA-34a promotes cardiomyocyte apoptosis post myocardial infarction through down-regulating aldehyde dehydrogenase 2. Curr Pharm Des, 2013; 19: 4865-4873. doi: 10.2174/13816128113199990325.

18. Cao L, Kong LP, Yu ZB et al. MicroRNA expression profiling of the developing mouse heart. Int J Mol Med, 2012; 30: 1095-1104. doi: 10.3892/ijmm.2012.1092

19. De Rosa S, Fichtlscherer S, Lehmann R et al., Transcoronary concentration gradients of circulating microRNAs. Circulation, 2011; 124 : 1936-1944. doi: 10.1161/CIRCULATIONAHA.111.037572.

20. Sonntag KC, Woo TUW, Krichevsky AM. Converging miRNA functions in diverse brain disorders: A case for miR-124 and miR-126. Exp Neurol, 2012, 235: 427-435. doi: 10.1016/j.expneurol.2011.11.035.

21. Boon RA, Iekushi K, Lechner S et al. MicroRNA-34a regulates cardiac ageing and function. Nature, 2013; 495: 107-110. doi: 10.1038/nature11919.

22. Hoekstra M1, van der Lans CA, Halvorsen B et al. The peripheral blood mononuclear cell microRNA signature of coronary artery disease. Biochem Biophys Res Commun, 2010; 394: 792-797. doi: 10.1016/j. bbrc.2010.03.075

23. Du L, Pertsemlidis A. Cancer and neurodegenerative disorders: pathogenic convergence through microRNA regulation. J Mol Cell Biol, 2011; 3: 176-180. doi: 10.1093/jmcb/mjq058. 
24. He F, Lv P, Zhao X et al. Predictive value of circulating miR-328 and miR-134 for acute myocardial infarction. Mol Cell Biochem, 2014; 394: 137-144. doi: 10.1007/s11010-014-2089-0.

25. Gidlöf O, Andersson P, van der Pals J et al. Cardiospecific microRNA plasma levels correlate with troponin and cardiac function in patients with ST elevation myocardial infarction, are selectively dependent on renal elimination, and can be detected in urine samples. Cardiology, 2011; 118: 217-226. doi:10.1159/000328869.

26. Goretti E, Vausort M, Wagner DR, Devaux Y. Association between circulating microRNAs, cardiovascular risk factors and outcome in patients with acute myocardial infarction. Int J Cardiol, 2013; 168: 4548-4550. doi: 10.1016/j.ijcard.2013.06.092.

\title{
Decyzyjne mikroRNA (miR-124, -133a/b, -34a i -134) u pacjentów z zamkniętym naczyniem odpowiedzialnym za zawał z ostrym zespołem wieńcowym
}

\author{
Jacek Gacoń1, Anna Kabłak-Ziembicka², Ewa Stępieńn, Francisco J. Enguita ${ }^{4}$, Izabela Karch², \\ Bogusław Derlaga ${ }^{1}$, Krzysztof Żmudka², Tadeusz Przewłocki ${ }^{5}$ \\ 'Oddział Kardiologii Inwazyjnej, Specjalistyczny Szpital im. Edwarda Szczeklika, Tarnów \\ ${ }^{2}$ Oddział Kliniczny Kardiologii Interwencyjnej, Instytut Kardiologii, Uniwersytet Jagielloński, Collegium Medicum, Szpital im. Jana Pawła II, Kraków \\ ${ }^{3}$ Instytut Fizyki, Wydział Fizyki, Astronomii i Informatyki Stosowanej, Uniwersytet Jagielloński, Kraków \\ ${ }^{4}$ Instituto de Medicina Molecular, Faculdade de Medicina, Universidade de Lisboa, Lisboa, Portugalia \\ ${ }^{5}$ Klinika Chorób Serca i Naczyń, Instytut Kardiologii, Oddział Kliniczny Kardiologii Interwencyjnej, Uniwersytet Jagielloński, \\ Collegium Medicum, Szpital im. Jana Pawła II, Kraków
}

\section{Streszczenie}

Wstęp: Zamknięcie tętnicy wieńcowej nie zawsze manifestuje się uniesieniem odcinka ST w elektrokardiogramie, a zawał serca z uniesieniem odcinka ST (STEMI) nie jest równoznaczny z zamkniętą tętnicą odpowiedzialną za zawał (IRA).

Cel: Celem pracy była ocena profilu krążących mikroRNA (miRNA), które różnicują pacjentów z zamkniętą IRA.

Metody i wyniki: Pacjenci ( $n=43)$ z niepowikłanym troponino-dodatnim ostrym zespołem wieńcowym podzielono na grupy z drożną vs. zamkniętą IRA oraz z zawałem serca z uniesieniem odcinka ST vs. bez uniesienia odcinka ST (STEMI vs. NSTEMI). W surowicy analizowano poziomy ekspresji następujących miRNA: miR-1, -16 -34a, -122, -124, -208b, -133a/b, -375 i -499. Spośród 16 pacjentów ze STEMI i 27 z NSTEMI okluzje IRA stwierdzono odpowiednio u 12 i 15 pacjentów. U pozostałych 4 chorych z STEMI i 12 z NSTEMI stwierdzono drożną IRA. W grupie STEMI stwierdzono wyższe stężenie troponiny T i 3,83-krotnie większą ekspresję miR-134 ( $<<0,025)$. W grupie z niedrożną vs. drożną IRA stwierdzono wyższy poziom miR-133a (krotność zmian: 7,00), miR-133b (4,57), miR-34a (5,50), miR-124 (2,55) i miR-134 (3.45), ale nie odnotowano różnicy stężeń troponiny T. Za pomocą krzywej ROC zidentyfikowano decyzyjne miRNA zamkniętej IRA: miR 124 (AUC: 0,787; $p<0,001$ ), miR-133b (AUC: 0,704; $p=0,006$ ) i miR-134 (AUC: 0,686; $p=0,016$ ). W grupie STEMI tylko miR-134 wykazało wartość różnicującą (AUC: 0,725; $p=0,002$ ).

Wnioski: Stopień zwężenia IRA określa poziom ekspresji krążących miRNA, a specyficzne miRNA mogą być użyteczne w podjęciu decyzji o pilnej rewaskularyzacji wieńcowej.

Słowa kluczowe: ostry zespół wieńcowy, mRNA, tętnica odpowiedzialna za zawał, STEMI, NSTEMI, okluzja

Kardiol Pol 2016; 74, 3: 280-288

\section{Adres do korespondencji:}

lek. Jacek Gacoń, Oddział Kardiologii Inwazyjnej, Specjalistyczny Szpital im. Edwarda Szczeklika, ul. Szpitalna 13, 33-100 Tarnów, e-mail: jgacon@o2.pl 